\title{
A Comparison between Practical Epistemology Analysis and Some Schools in French Didactics
}

Per-Olof Wickman

\section{(2) OpenEdition}

\section{Journals}

Édition électronique

URL : http://journals.openedition.org/educationdidactique/1456

DOI : 10.4000/educationdidactique.1456

ISSN : 2111-4838

Éditeur

Presses universitaires de Rennes

\section{Édition imprimée}

Date de publication : 30 octobre 2012

Pagination : 145-159

ISBN : 978-2-7535-1984-8

ISSN : 1956-3485

Référence électronique

Per-Olof Wickman, «A Comparison between Practical Epistemology Analysis and Some Schools in French Didactics », Éducation et didactique [En ligne], 6-2 I octobre 2012, mis en ligne le 30 octobre 2014, consulté le 08 décembre 2020. URL : http://journals.openedition.org/educationdidactique/1456 ; DOI : https://doi.org/10.4000/educationdidactique.1456 


\title{
A COMPARISON BETWEEN PRACTICAL EPISTEMOLOGY ANALYSIS AND SOME SCHOOLS IN FRENCH DIDACTICS
}

\author{
Per-Olof Wickman (Stockholm University)
}

\begin{abstract}
The aim of this article is to introduce the Swedish approach Practical Epistemology Analysis to the French community of comparative didactics, and to compare it to two major schools in French didactics to see how they are compatible and could draw on each other. This is made with an empirical emphasis, examining how the theoretical constructs can be operationalized to examine classroom interactions for didactical purposes. The French schools reviewed here are The Theory of Didactical Situations and Joint Action Theory in Didactics.
\end{abstract}

Per-Olof Wickman

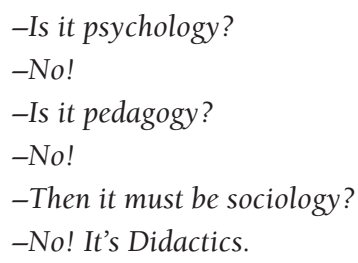

\section{Introduction}

According to Michel Caillot (2007) the aim of comparative didactics as a field of research is to compare the concepts and the methods that are used in didactics, whatever the disciplinary field. The goal is also to productively relate disciplinary didactics to the social sciences. The purpose here is to accomplish this degree of generality, while at the same time not losing sight of the specific content taught and learnt in the classroom (sensu lato) interactions. As is also standard procedure in comparative didactics, I will also draw on philosophy, and especially philosophers with a naturalistic bend. This is because, as I will argue, we need to consider some basic philosophical assumptions before we can proceed with our didactical endeavors.

It is common in the disciplinary field of didactics ${ }^{1}$ to import frameworks from related fields of research, may it be psychology, pedagogy or sociology. However, there is always a problem in importing theories and methodologies that have been developed for other purposes. To paraphrase the American neopragmatist philosopher Richard
Rorty (1991), epistemology is not just a question of getting reality right, but one of developing habits for coping with reality. And doing always means that certain aspects of frameworks need to be made more salient and also be transformed in a purposeful way by human actors. French didactics for many years has been in the forefront in developing theories particularly suited for the questions and purposes that are pursued in didactics (Caillot, 2007), not just copying, but transforming and adapting frameworks from other fields.

Didactic research is of a more recent date in Sweden. Nevertheless, in the last decade, similar efforts have been made in developing theories particularly suited to didactical ambitions. One development is known as Practical Epistemology Analysis, and its purpose is to study how the transactions of the classroom influence the meanings made and so what the students are afforded to learn (Wickman, 2004; Wickman \& Östman, 2002a). To introduce this approach in the French context, I compare it to two major trends of French didactics, all tracing their origin to the discipline of mathematics, namely The Theory of Didactical Situations (Brousseau, 1997), and 
the most recent theoretical advances related to the Joint Action Theory in Didactics (Sensevy, SchubauerLeoni, Mercier, Ligozat \& Perrot, 2005; Sensevy, 2009; Ligozat \& Schubauer-Leoni, 2009).

My aim with this article is twofold. The first aim is to introduce Practical Epistemology Analysis to the French community of comparative didactics, and the second one is to compare Practical Epistemology to the two mentioned approaches in French didactics to see how they are compatible and could draw on each other. This is made with an empirical emphasis, examining how the theoretical constructs can be operationalized to examine classroom interactions for didactical purposes. Here I must stress that my review is restricted to publications in English, and also that the format of a journal article puts limits on the scope and completeness in covering all these theories. I direct the reader to the cited literature for a more in depth treatment and for further examples of use.

\section{What is Didactics and its epistemology?}

Before going into the details of the Swedish and French schools of didactics, it is necessary to clarify the meaning of didactics, its aims and its epistemological commitments. I claim that didactics gets its legitimacy as the teacher's profession science, no matter the level of education. It aims at improving the teacher's systematic knowledge base for making decisions about teaching and how to purposefully organize human and material interactions in the classroom $^{2}$. As claimed by Caillot (2007), a specific subject, topic or content is always involved. This content should not be understood simply as a given school subject or academic subject. The teacher always needs to transform the content of some topic in interaction with their students (Chevallard, 2007; Tiberghien, 2007), and that content should not be taken exclusively from academic research (science proper), but from student experience and society at large (Roberts, 1982; Wickman, Liberg \& Östman, in press).

The three basic questions of didactics traditionally are:

- What? (Choice of curriculum content)
- $\quad$ How? (Choice of teaching methods and settings)

- Why? (Reasons for these choices)

Of particular importance is the question about why. It entails developing concepts and systematic knowledge about the processes of how certain choices of content, methods and settings for teaching result in a certain content learnt, and that support informed judgments about the value of this learning. It is the systematic didactical knowledge that teachers need in improving their choices in their extended transactions with students and the moral and political landscape of schooling. It extends research into areas not only about how students with different background learn most efficiently, but also about our values and the situatedness of teaching (Östman \& Almqvist, 2011). These questions cannot be answered on purely rational grounds by using crude theories from psychology, pedagogy or sociology. They need to be studied empirically with theoretical frameworks that support didactic aims.

The notion of joint action, as developed in French didactics (Ligozat \& Schubauer-Leoni, 2009; Sensevy, 2009) is a comprehensive and pragmatic designation to summarize what the teacher is up for in her job, namely the joint action of the teacher together with her students resulting in the growth (progression) of students. Teaching and learning are traditional ways to summarize this joint action, but the connotations of these two separate terms are probably too transmissional without the uniting comrade-in-arms joint action. The joint action of classrooms necessarily is a genuinely transactional process of mutual transformation, that is not fully determined beforehand, but largely contingent (Hamza \& Wickman, 2009). This is why classroom transactions need to be studied empirically and also why a continuously reflecting teacher is needed in the classroom. The unfolding of events in the classroom cannot be fully planned, controlled beforehand or predicted by theory, neither by the researcher, nor by the teacher (Sensevy et al., 2005). This does not mean that it is impossible to find generic knowledge in didactics; quite the reverse. However, it means that the knowledge produced needs to be of a kind that can be purposefully transformed in encountering contingences when making decisions about teaching. 
The situatedness of the joint action in the classroom at the same time reminds us of the problem that every teacher eventually has to leave the student on to other places of joint action, and so also prepare the student for other communities. Devolution in Brousseau's (1997) parlance is a succinct way to talk about what is needed in the classroom. The question then is how this joint action is to be enacted in the classroom so as to support this devolution of the joint action of the teacher and the students to the joint action of the growing person and other people in our societies. The devolution for a didactic researcher is two-fold: the devolution of research findings from the researcher to the teacher, and the devolution from the teacher to the student. Part of this devolution is also a transposition of the subject matter from some source of historical origin to teaching (Brousseau, 1997; Chevallard, 2007).

With a structuralist and reproductive view of human thinking and communities, this devolution may seem an impossible task; it can never be the same in research, school and society. However, dropping the notion of sameness, and adopting a transactional pragmatist understanding instead, it seems possible. Although two situations never are a perfect match, the teacher can improve (meliorate) the situation for the students by helping them to transform knowledge and by making situations continuous in action. The criterion to judge learning is not whether it is the same in two situations, but rather if something learnt in one activity helps students to proceed in another one.

Knowledge cannot be simply transferred and used as ready-made between two persons. It is always transacted in use (Dewey \& Bentley, 1949/1975; Öhman \& Östman, 2007) in relation to the purpose and the content of an activity that is part of a life and a culture (Dewey, 1938/1997; Lave, 1996). This is not a process of de-contextualization, where knowledge from one context is made abstract and non-situated, before it is re-contextualized again; it is a process of getting to know in action. Knowledge is always meaning, in transaction in doing something, and never absolute and abstracted from a context of use (Wickman \& Ligozat, 2011). Generalization of knowledge is the process of adding uses and activities to earlier uses and activities, where the learner in action takes the two uses as continuous (Wickman \& Östman, 2002b). In this way knowledge always entails transformation and therefore learning.
In what follows I will interpret and compare some central themes in French didactics from my pragmatist and socio-cultural stance. We need to remember here that the French approach has developed within Mathematics Education, whereas the Swedish one originally was a result of Science Education. But the program of comparative didactics gives the courage to make the comparison.

Before dealing further with French didactics and the comparison, I want to give some basics of how I understand pragmatism in relation to the didactical questions related to earlier, and how they can be dealt with in terms of the Practical Epistemology Analysis (PEA) developed in Sweden.

\section{A short introduction to Pragmatism and PEA}

The basic principles of Practical Epistemology Analysis (PEA) are inspired by John Dewey (1922; 1929/1958; 1938/1997) and the writings of the late Ludwig Wittgenstein $(1967 ; 1969)$. Our institutions, culture and form of life (without distinguishing its origin as nature or nurture) constitute the integrated medium in which the child is born and develop. In this development the customs of society are transformed into the habits of the growing person. These habits are not just how we move our bodies, but also the ways and content of our communications as for instance talk, reasoning and judgments. They all constitute action, as they are set in various activities with purposes. Learning in this way is not about getting reality right, but about purposefully transforming habits to cope with life. The start then is always an historical setting, where there are certain activities carried out in habitual ways as part of customs, traditions and institutions. Purpose in this use should not be understood as hidden psychological intentions, but as shared in institutional communication, answering the central question of Goffman (1974, p. 25): "What is it that's going on here?" - an answer that we need to embody in action to make sense of an activity. People can take part in an activity when they see the purpose of the activity, because purpose is something you do in discerning what acts are relevant and not relevant in the particular setting. As an analytical concept purpose in this sense transcends the individual and one particular setting; it becomes evident from the participants' anticipations and responses 
to the actions of each other as part of institutional customs (cf. Sensevy, 2011b). This is why we as researchers, as being familiar with teaching, can make sense of what is going on in classrooms. If the purpose is not evident to the researcher from what is going on in the classroom, not only the researcher, but also the students will probably have difficulties in making sense of the lesson.

Habits in its pragmatist use are complex ways of coping in life. They can only be transformed slowly, because any change will affect other constituent parts of them and so the activity as a whole in a nonreductionist way. Dewey (1922) uses the example of himself trying to change the way he stands. Any change in the position of his neck will change his whole bodily balance and the relative position of all other body parts. The work to change habits need to consider that they typically need to function in relation to the activity as a whole and as part of an institution. We cannot stop standing and learning new ways of standing that are more purposeful outside of this activity of standing and its different uses in our life. Dewey called this whole "experience". We cannot question everything, certain ways of acting are beyond questioning or even doubt. It has no meaning to question them because they have no consequences as part of our doings. These things can be said to stand fast adopting Wittgenstein's (1969) terminology. If we were to question everything, and start completely from scratch, we could not act. The boat has to be rebuilt while sailing on the sea. In similar way teachers cannot separate themselves from the institutions where they work and come up with completely new habits of teaching. Also they need to transform their habits while teaching in certain institutions.

John Dewey suggested a method that I will refer to as the Empirical Method for such transformations. It is an important complement to PEA and fundamental to it by offering a means of reflection to change habits in a purposeful way (Dewey, 1929/1958, pp. 1a-39). Despite its name it is not merely empirical, but rather a method based on making reflection as well as empirical consequences continuous in a purposeful way for action. The name is to emphasize that theoretical reflection cannot be our sole guide for action. It suggests that we 1) start from a habit, custom or institution where a problem arises and something needs to be meliorated, 2) we then suggest new ways of making distinctions (new concepts or actions to be taken) to improve the situation, and 3) we examine how these new ways of making distinctions are continuous with our prior experiences (including habits, customs and institutions) and how they help us to better proceed with our purposes. Step two is mainly rational, although based on experience. Step three is necessarily empirical. To Dewey there is no final theory that can be adopted uncritically to improve our life, or for that matter education. The Empirical Method therefore needs to be iterated continuously and in a nested way as many of the consequences are contingent on specific circumstances.

The Empirical Method is related to Dewey's (1938/1997, p. 35) principle of continuity. According to this principle every current experience takes up something from prior experience and has consequences for future experience. That something makes sense is not tantamount simply to it being true or an inner state of seeing as, but as being continuous in proceeding with purposeful undertakings as part of institutions. Important here are the consequences of the different ways to proceed in relation to purpose; they decide if the new way is to be preferred rather than the old one. Although this decision should be based on evidence, at the same time it is always also situated within the prior experiences (habits, customs, values, institutions) of those affected by the change, which inevitably are taken into consideration for future action. Solutions are not universal and eternal. Due to contingency and situatedness in certain activities they need further melioration. This is also why psychological, pedagogical or sociological theories cannot be imported directly into didactics; they need to be adapted to didactical purposes and circumstances.

The aim of Practical Epistemology Analysis is to study learning and teaching according to these didactic and pragmatist principles using a number of operational concepts (Wickman \& Östman, 2002a; Wickman, 2004):

- The purposes of teaching (proximate and ultimate purposes)

- Continuity: The joint filling of gaps by the construal of relations to that which stands fast depending on the encounters that occur in the classroom 
- $\quad$ The development of new habits and customs as part of teaching

These three aspects are related to each other. They are not psychological constructs, but operational ones for empirically analyzing classroom talk and action in the form they are encountered by the teacher. The concepts are operationalized as explained below.

The purposes are descriptions of the kinds of activities that students are supposed to become competent in. The proximate purposes are typically evident from the classroom activities that are analyzed. Sometimes interviews or work sheets are needed to clarify the ultimate purposes, when their consequences in action are not apparent from the doings in the classroom. However, the primary purpose for analysis is always about "What is it that's going on here?", that is, what students can be seen to be up to in the classroom. Without such a first person purpose, it is not possible to analyze the sense that students and teacher make jointly of the activities of the classroom.

That which stand fast are all the words and actions that teachers and students use without asking what they mean. They simply use them. This may be a problem, because they use them in a way that makes them proceed with an action that is not conducive to purpose. However, normally words and actions function well for our purposes, and most of the words and actions students and teachers use habitually work (has to work) without asking what they mean. Stand fast is a very situational term, which means that a certain word may stand fast in one situation as part of an activity, but not in another. For example in doing a chemistry lab practical, university students were asked to use the colors to identify different solutions in a number of test tubes. Although color is a word that normally makes sense in conversations, in this case the students in a humorous way asked what counted as color in this chemistry lab (from Wickman, 2006, p. 111):

Eva: So they [the test tube solutions] are fully natural colors then?

Teacher: Yes. Some may be a little discolored.
Anna: So you didn't put any dye in or anything?

Teacher: No, no, why would we do that?

Fatima: To make it nice.

Teacher: No, this is nature. It's nice the way it is.

The students later got to learn that some of the solutions in the test tubes were "discolored", and that although they had color in an every-day sense, they did not have any color in a sense that had consequences for this particular lab practical. If students had not asked about the meaning of the word color in this practical, that is, that it had stood fast in an every-day sense, they would perhaps not have been able to proceed with the purpose of identifying the solutions of the test tubes.

Learning can proceed when students construe relations between different actions or between words that stand fast as part of a specific activity. In the chemistry lab practical mentioned above, the teacher tried to find words that stand fast in the situation and construe relations between them, making the students proceed with the activity. For instance, he construed a relation between "some" and "may be a little discolored". Later he construed the relation between "nature" and "nice the way it is". So, for students to make sense of an activity, it is not enough that words stand fast per se, but only as part of the new relations construed to make the activity proceed.

When students proceed, the relations they construe are said to be filling gaps. The fact that students construe relations (with or without the teacher) shows that they need them. However, students and teachers may also come up with actual questions, which also constitute gaps that need to be filled by the students with relations. Some questions the students may not be able to answer, and such gaps are said to be lingering. In the excerpt above the students can be said to have noticed a gap about what counted as the color of a solution. This gap was filled with different relations in the short excerpt related to. After this conversation the students proceeded by checking the colors, which suggests that the gap at least for the moment had been filled. However, the gap was returned to later when students encountered a solution that was discolored according to the teacher. The gap was again filled 
when the students used the relations construed with the teacher about this to proceed with the purpose of identifying the solutions. An example where a gap lingered is the following transcript from an insect lab practical, where university students were supposed to look for the ocelli ${ }^{3}$ on a pinned bumble bee (from Wickman \& Östman, 2002a):

L: Do you see those ocelli anything then? It has that too, doesn't it?

M: Usually you of course see it only like, well ...

L: Dots here.

M: Yeah. Ocelli, what kind of thing is that?

L: It's some other eyes. Those are compound eyes. They consist of many eyes together. Ocelli, it's, I suppose, like one eye that ...

M: Okay ... (writes and says:) eye

L: Hhhh (sighs). I think one has a picture of it somewhere.

(They discuss other matters for a while.)

L: (reads:) "Class Hexapoda ${ }^{4}$." Here we have, look, (reads:) "ocelli." They're so small! They're there somewhere.

M: In that case it is not possible to see.

L: No. (reads:) "Mouthparts, antennae." Do they have any antennae?

M: No, they usually do though, don't they? In cartoon films they usually have antennae.
L: Yes, or ocelli or both perhaps. I don't know. Yes it sounds as if all have compound eyes.

M: (mumbles:) apparatus ...

$\mathrm{X}$ : Yeah, I think that almost all have that. Maybe not all that have ocelli but ...

L: But they may have that too.

$\mathrm{X}$ : Yes, they have that I suppose.

The purpose here was to look and see on the real insects how they were built, and not to find the answers in the literature. The gap here was if the bumble bee had ocelli and what they looked like. We can see that the students could not find them on the bumble bee, and so could not say what they looked like on this particular bumble bee. This gap was not filled with any relation, and so it lingered.

The encounters that occur influence the meaning (the relations that can be construed). Encounters are all those things that can be seen to meet during the classroom activity studied: the objects as well as the students and the teacher. In the last excerpt an important encounter according to the purpose of the lab was the encounter with real insects as opposed to texts or images of insects. Also an important purpose of this specific teaching sequence was that the students should try to see for themselves, and not ask the teacher. The PEA in this case concerned what students could learn (relations construed) about how insects were built in encounters with real insects and in encounters with other students, but not with the teacher (Wickman \& Östman, $2002 \mathrm{a}$, b). The concepts of PEA are summarized in Figure 1. 


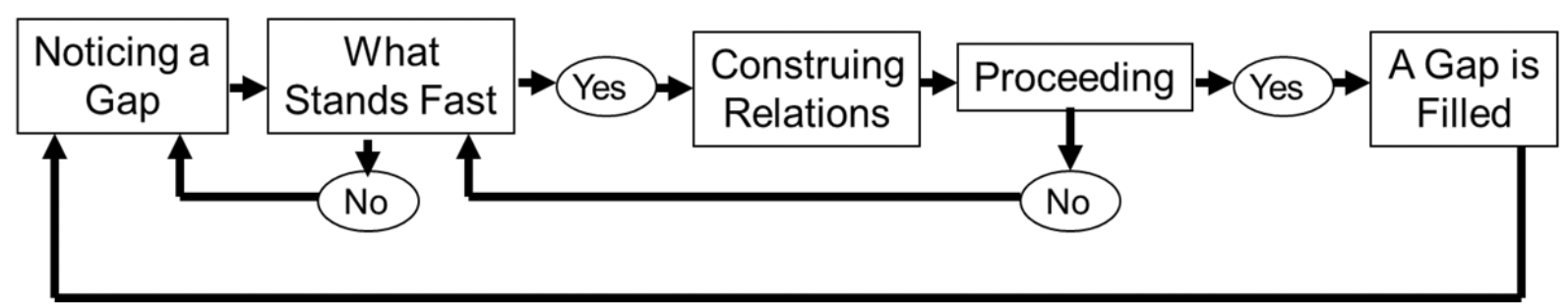

Figure 1. A general outline of the basic concepts (gap, stand fast and relation) of PEA and how they can be applied to the progresses of the learning process according to purpose. Encounters influence each and every step. The teacher should try to organize encounters so that students a) notice certain gaps, b) use what stands fast in the moment to fill the gaps with relations, and c) proceed fruitfully with their undertakings according to purpose.

By using PEA in studying classrooms it can be seen how different encounters and what stand fast influence how students proceed and hence are afforded to learn (gaps noticed and relations made) in terms of the purposes of the lesson, and thus how teaching needs to be changed to accomplish purposes better. In a longer time perspective habits can be seen to develop as action patterns of individual students or as customs of groups of students (Wickman, 2004; 2006). It should be noted that many of the encounters actually observed are highly contingent and unique occurrences (Hamza \& Wickman, 2009). An important question accompanying PEA analysis is therefore "To what degree are the gaps noticed and the relations construed contingent upon the specific encounters?" And "Could consequences be made less contingent?" Contingencies are not to be removed (and they cannot be removed completely) but need to be related to by a teacher who is attentive to the practical epistemologies as they develop in the classroom. The PEA terminology is developed in terms of what a teacher can observe as happening in the classroom. It is about the visible actions, not about psychology.

\section{The Theory of Didactical Situations}

Guy Brousseau's Theory of Didactical Situations (TDS) in mathematics can be described from how he approaches on the one hand the content of teaching and learning, and, on the other hand, the methods of teaching and learning. This section on Brousseau, focuses some concepts of his that can be operationalized for didactical purposes to answer mainly the how and why questions. I will not examine
Brousseau's theoretical foundations per se, but look at their consequences for didactics. This approach applies generally to the review of French didactics that now follows. This section draws mainly on Brousseau (1997).

Brousseau has an interesting and original idea about creating a community in the classroom, which with some necessity will produce a desired piece of knowledge in mathematics. This community is built upon creating certain material conditions and upon relegating certain roles to the teacher and the students as players in a game. This game in the end must allow the derivation or modification of concepts imported from the discipline of mathematics. This is a process of 1) recontextualization from an adidactical situation to a didactical situation, and 2) repersonalization of the knowledge as devolution from the teacher to the student.

The adidactical situation is used to introduce the game, and is one in which the students can act without knowing the broader situation of the piece of knowledge to be learnt, that is the didactical situation. In pragmatist parlance I would say that an activity is set up in which the student can act purposefully without yet knowing the piece of knowledge taught, but in which the teacher and student can trust that this piece of knowledge is learnt by the students as the activities takes their course. Hence, the teacher does not give them this piece of knowledge directly, but devolution is said to occur, because the students need the knowledge in playing the game to its conclusion.

This means that Brousseau's theory of didactical situations is not simply a psychological theory, but 
builds on his ideas about how the material conditions of the classroom and the social contracts can be set up between the teacher and students that will result in relevant learning on behalf of the students. At the same time it means that teaching is modeled on a game activity.

The game as a whole is built from three steps. In the first step the adidactical situation is given to the students and they are to practice the rules of the game so they can play it out. The game of this adidactical situation typically has an aim that is easily spotted by the students. In the second step, the students are asked to find ways together to improve their actions, so that they more easily reach the aim of the game. In the third step they are supposed to develop justifications for their claims. In this last phase concepts are imported from the scientific field, which in this case is mathematics. These three steps are called action, formulation, and validation.

Ideally a game presupposes a didactical contract, where there are social responsibilities that result in the devolution of a problem from the teacher to the students. The teacher must always be prepared to change the contract if the devolution does not occur. Hence, Brousseau is aware of the possible contingent transactions between the students and teacher, and that the teacher continuously has to monitor the development of the contract in the classroom. This is one of the important purposes of PEA, to support the teacher and researcher with analytic tools to monitor this development of the mutual roles of the students and the teacher about what is counted as knowledge and their consequences for student learning (their practical epistemologies). The didactical contract has been used also by science education researchers to analyze the norms and expectations of classrooms (Tiberghien, Vince, \& Gaidioz, 2009; Gyllenpalm $\&$ Wickman, 2011). Nevertheless, it needs to be pointed out that to Brousseau the didactical contract is a resource to be designed and used deliberately in creating purposeful lessons.

Interestingly enough, the TDS shows some critical similarities to the Empirical Method (Wickman \& Ligozat, 2011; Johansson \& Wickman, 2011). The three steps of Brousseau in designing a teaching unit could be reinterpreted as a special case of this method. The first step in identifying an activity that is familiar and makes sense to the students is exemplified in TDS by the game. In this way a customary activity is established in the first step. In the second step the students are asked to reflect on the proximate purpose of the game, that is, of winning the game. In the third step, when students are to develop justifications for their claims, reflection makes contact with the ultimate mathematical purposes. However, this last step also encompasses an empirical aspect in the sense of PEA, namely that these reflections are brought back to the game, where they should be possible to use in demonstrating that they improve a winning strategy.

In this way the first step and the initial stage of the second step of TDS can be seen as tantamount to the first step of the Empirical Method, that is that of identifying an activity which is familiar to the students and which gives them an end-in-view (proximate purpose). The last part of the second step and the first part of the third step of TDS resembles the second step of the empirical method, which entails reflecting on how the activity could be improved by making the proximate (winning the game) and ultimate purposes (using mathematics) continuous. The last step of TDS in terms of the Empirical Method is that of bringing back the suggestions of reflection to the customary activity to examine if they have the desired consequences in improving the activity. This situates the "situation" in life and gives academic knowledge meaning.

These customary activities do not have to be farfetched. An example from a design study by Peter Hubber, Russell Tytler and Filocha Haslam (2010) with the purpose of developing representational modes in physics can illustrate how the Empirical Method could be adopted in science education ${ }^{5}$. In their study they illustrate how various representations were used by a teacher in teaching a sequence on force in Grade seven. Students were first asked by their teacher Lyn to mould a lump of Plasticine (a clay-like material) to different shapes. This was an activity with an easily spotted end-in-view to the students. Lyn then made a communicative intervention of reflection together with the students asking them about words they would use to describe to someone else what they had done to mold the lump of Plasticine. The students suggested every-day words like "stretch, carve, twist," and so forth. The teacher 
then helped the students, by making gestures, to list them under the headings of "push" and "pull". She then introduced the term force as meaning the push or pull of one object onto another. This can be seen as the first two steps of the Empirical Method of introducing a familiar proximate activity (molding Plasticine) and then reflecting on the activity conceptually, so as to make a connection between the proximate purpose and the scientific activity that is yet unknown to the students, and which has a more scientific purpose dealing with the use of the concept force. These new scientific concepts of force as push and pull now needed to be brought back to the proximate purpose of molding Plasticine as a social activity.

With such a purpose, the teacher now let the students draw various representations on paper to describe how they molded their lump of clay. The class then discussed these different kinds of representations in terms of an additional proximate purpose, namely that the students should use their representations of force as push or pull to explain to someone else how they could mold a piece of Plasticine to the same shape as theirs. In doing this the concept of force was brought back to the proximate activity of molding Plasticine to different shapes. In a discussion with the class, the teacher Lyn let the students compare the different representations. The purposefulness ${ }^{6}$ of John's use of arrows stood out in the discussion:

Lyn: Which one of these representations worked well in explaining what was done?

Student 1: John's because it showed you exactly what to do. Mine could have ended up anything.

Student 2: It was more visual, you can actually see it is easier to actually see what you did. With the other ones you could make it in different ways. (From Hubber et al., 2010, p. 12)

Here we can see how the reflection about force as push and pull is brought back to the proximate activity to show its consequences in use, and at the same time expanding it to make the proximate purpose of molding Plasticine continuous in the shared classroom experience with the ultimate scientific purpose of teaching students about force as being represented by arrows to demonstrate the direction of a force. The reflection in the excerpt about using arrows then needed to be refined further in continuity both with proximate and ultimate activities.

Here I refer to the situations of TDS as activities. According to such an understanding, the adidactical situation is the familiar activity with a proximate purpose that functions as an end-in-view to the students. The didactical situation is the activity with an ultimate purpose. We have distinguished between proximate purposes (ends-in-view, adidactical) and ultimate purposes (didactical) of the activity, and asked the empirical question how these can be made continuous in the joint work by the teacher and the student. The idea is very much that the two activities are one and on equal footing. The scientific concepts are never decontextualized, but put in use (recontextualized) and valued in terms of their consequences. The proximate purposes and the activity of which they are part is not just a game to learn the ultimate purposes (conceptual or more general knowledge), but also there to teach the students how to deal with more mundane activities (here shaping things) of value to them and society, how trivial they may seem in isolation.

The situation is not external to the student or the teacher, but something they take part in together (joint action in the activity, i.e. the situation). This means that the scientific concepts used are valued for their consequences for improving the purposes of the proximate activity, in the activity and not merely for how well they teach the scientific understanding per se. The didactical aim is not just to teach the students the academic understanding, but to become literate in a wider sense. It is important that the ends-in-view have an authentic relation to the life of the students.

However, there is more to what is called a situation in TDS than the didactical contract and the social responsibilities that it assigns to the teacher and the students. Similarly, in PEA and in adopting the Empirical Method there is more than just the encounter between the teacher and the students and the roles that they play for the epistemology developing in the classroom. There is also a material setting and an institution in a wider sense. The Plasticine and the various representations from science are examples of this. There are already certain esta- 
blished ways of doing things and also habitual ways of communicating that need to be used to be able to participate in joint action and activities, in the classroom as well as elsewhere.

This more material setting is the milieu of TDS; "Everything that acts on the student or that she acts on is called the "milieu" by Brousseau (1997, p. 9). Just like the didactical contract, Brousseau sees the milieu as a resource in setting up a situation. Ideally the social interactions of the didactical contract, and the material interactions with the students of the milieu should be arranged in such a way that they are conducive to the aims of the lesson. Again Brousseau offers a theory for classroom interaction, without giving much help of how to monitor these interactions unfolding in the classroom, and to what degree they in real classroom settings are conducive to purpose. For this support he lends just psychologically oriented theories on learning, to argue for his case. Here, PEA offers the operational notion of encounters, which can be used to empirically analyze how the different transactions of the classroom actually are conducive to the learning aims of the lesson.

The theoretical terms milieu and didactical contract need an analytical operational term to identify their critical components when played out in the classroom. Just like the didactical contract and the milieu, the encounters are what the teacher can influence, although absolutely not completely, but desirably in a decisive way for the learning to take place. Ultimately the epistemology and resulting learning that develops to a large degree is contingent on the encounters and hence needs to be examined empirically to discern more general patterns that can be employed to meliorate the continuity (filling gaps with relations to what stand fast) in the activities used. I would also like to emphasize that the milieu, the didactical contract and the encounters that occur as part of them need not be external to the student. Not just the current experiences, but also those previous experiences related to by the students are encounters. The encounters are all the things and persons that the students meet as can be observed by the teacher or researcher through student action and talk. An example where the students encounter things from previous experience is illustrated by the earlier excerpt, where students studied bumble bees and mentioned the way insects look in cartoon films. Apparently, through the experience of one of the students there is an encounter with how insects look in cartoon films during this lesson. Because of such often contingent transactions with earlier as well as current experiences, the teacher can never fully control beforehand what is going to happen when the didactical contract and milieu is unfolding in transaction in the classroom. It needs to be carefully monitored by the teacher by using appropriate tools or heuristics. The teacher by all means needs help to develop her understanding how this continuity can be furthered and how different activities can be made continuous for the growth of the students according to purpose. PEA is a method to reason about this.

As an important side issue, Brousseau's idea about the overarching role of pleasure in the game is interesting from a pragmatist point of view and that according to him no other goal as such is needed for the adidactical situation to evolve. According to a pragmatist stance pleasure/displeasure (aesthetics) is always integrated (continuous) with the cognitive and normative aspects of an activity. Through aesthetic experience students develop a certain taste about what belongs and do not belong in an activity, including their own affiliation. Operationally the importance of aesthetics to continuing action can be observed as the interplay between anticipation and fulfillment (Wickman, 2006). What is anticipated as supporting action in a desired direction and that actually leads students to participate in accomplishing fulfillment of tasks, is related to by students in positive aesthetic terms. Hence, the separation of pleasure and other kinds of goals is artificial. When Brousseau's idea of pleasure is interpreted in such a more holistic sense, there is an important similarity between the two approaches about the centrality of aesthetics to teaching situations. If the consequences are desired, students often say that the lesson was fun.

To conclude, a crucial difference between the Swedish pragmatist stance to teaching and learning (Practical Epistemology Analysis and The Empirical Method) and the Theory of Didactical Situations of Brousseau is the more empirical stance of the former and the more theoretical stance of the latter in approaching learning processes. Most importantly PEA and the Empirical Method offer a way 
to empirically monitor the epistemologies and learning that develop in the classroom, and to which Brousseau mainly offers theoretical rationalizations. Nevertheless, the steps of reasoning about how a purposeful teaching situation (activity) can be set up bear many similarities. The comparison between these two approaches suggests that there are commonalities to setting up teaching situations in mathematics and science, and that such situations can be understood as the relation between different levels of purposes that need to be made continuous through joint action in the classroom.

\section{Joint Action Theory of Didactics}

In the English literature the Joint Action Theory of Didactics (JATD) can be traced to a paper by Gérard Sensevy, Maria-Luisa Schubauer-Leoni, Alain Mercier, Florence Ligozat and Gérard Perrot (2005). This is very much a paper primarily aimed at developing a model for describing teachers' actions as part of teaching processes, but in extension it is also possible to use in transforming them. It explicitly states its origin from TDS and Yves Chevallard's (2007) Anthropological Theory of Didactics (ATD) ${ }^{7}$. By comparing what becomes of Brousseau's lesson "The Race to Twenty" in different classrooms with different teachers, they demonstrate the non-deterministic nature of Brousseau's teaching situations, and that they are highly dependent on the teacher's local understanding and transposition of the situation.

Central concepts are nested in an analysis on three levels:

1. The interaction of mesogenesis, topogenesis, and chronogenesis

2. The relationship between contract and milieu in learning games

3. The teacher's beliefs and usual ways

Here I will especially highlight the three concepts of the first item as they are very helpful in discerning and describing important components of the teaching as related to what students are afforded to learn. These three concepts play an important part in the later developments of the JATD (Ligozat $\&$ Schubauer-Leoni, 2009; Sensevy, 2009). Apparently the three concepts of mesogenesis, topogenesis, and chronogenesis trace their origin to Chevallard's ideas about didactical transpositions (Sensevy et al., 2005). The concept of joint action has found support in Herbert Mead's ideas about the social nature of action, where communication is seen as mutual adjustments of behavior among individuals in carrying on a process (Sensevy, 2011a). Hence, it has close relationships to a pragmatist understanding of transactions between people.

Interpreting Sensevy et al. (2005), mesogenesis is a description of the processes that organize the material encounters of the students in the specific situation (i.e. the milieu). It answers questions about what procedures the students are going through and what objects they meet in the situation (activity). Topogenesis concerns the division of the activity between the teacher and the students (i.e. the didactical contract). It answers questions about who of them is responsible for furthering the situation (activity). Chronogenesis describes the evolution of the knowledge proposed by the teacher and studied by the students, i.e. the sequencing of the situation and how much time (in a qualitative sense) is spent on the various interactions. It answers questions about how teaching and learning is ordered in time over the situation.

What JATD do most importantly for empirical didactical purposes is to supply a framework for directing researchers to the critical aspects that a teacher can influence in a teaching sequence and how they are ordered in a time sequence. In this way JATD takes TDS further from being a theory about how to organize teaching to one that can be used to describe what is actually happening in the joint actions of the classroom. Still, JATD do not offer a means for analyzing how the various encounters and their sequencing afford learning of one content rather than another. In this way PEA could be used to supplement the argumentation from data to create a firmer basis to improve the mesogenesis, topogenesis and chronogenesis according to the purposes and aims of a lesson. Also the Empirical Method could be used to for similar purposes to study how the different levels of purposes are made continuous, so as not to forget the important observation made by 
Brousseau about how there are adidactical and didactical situations that need to be mutually supportive for students' learning.

\section{A Didactical Theory of Joint Activity}

Recently these ideas about how JATD, PEA and the Empirical Method could be used jointly to monitor and assess teaching situations and sequences have been applied to the teaching of mathematics in elementary school (Ligozat, Wickman \& Hamza, 2011). The lesson studied had the ultimate purpose of teaching students about area from the more proximate task of ordering geometrical shapes according to their size. The analysis shows how the mesogenesis, topogenesis and chronogenesis hinders and support students in making these two purposes continuous and it also suggest changes that can be made in these three aspects to help students better generalize the concept of area.

To conclude I would like to emphasize that this paper is just a first effort to combine and compare the ideas of French Didactics with those that have been developed as part of Practical Epistemology Analysis in Sweden. Although there are many points that have not been treated in this article (especially theoretical ones), and that may not be fully compatible, still there are many points of common interest that can be developed further to produce a "Didactical Theory of Joint Activity". I understand that I may have misinterpreted some of the ideas developed within French Didactics. However, my intention has not been to give a true representation, but rather to develop approaches that could be used to better cope with didactical situations. I hope I have clarified some issues where cross fertilization could be advantageous, especially with an empirical and didactical focus on research.

\section{Acknowledgements}

A draft of this paper was first presented at the seminar Culture(s), Institutions \& Didactical Transactions (CITD): What fundamentals for developing comparative researches in didactics in Europe, March 8-12th, 2010, Faculté de Psychologie et des Sciences de l'Éducation, Université de Genève, Geneva, Switzerland. I want to thank all participants for their comments that have helped improving the manuscript. Especially I want to thank Florence Ligozat and Gérard Sensevy. Florence has been helpful in clarifying many aspects of French didactics in continuous discussions and helped me relate them to PEA. She also gave extensive critical but supporting comments to this paper. Gérard encouraged me to finish my draft and submit it for publication in Education \& Didactique. I also thank Gérard for allowing me to quote him on the significance of games in teaching. Although all this support has been important, I am fully responsible for the claims made in this paper. 


\section{NOTES}

1. I do not use this term in its common English sense (see e.g. Caillot, 2007), but to designate the French disciplinary field of didactiques, which corresponds to didaktik in Swedish.

2. By this I do not mean that didactics is restricted to research on what can be directly used by teachers. Didactics as the science of teachers should be understood in the same sense that economics is the science of economists, medicine the science of physicians, engineering the science of engineers, agronomy the science of farmers etc. For instance, medicine cannot stand isolated from the science of biology, but nevertheless medicine does not have the same aims as biology. The results of biology need to be adapted to eventually be of clinical use. In didactics especially the question of why necessitates knowledge that transcends disciplinary borders.

3. Ocelli are much smaller than the compound eyes and can be difficult to see on a hairy insect like a bumblebee.

4. Hexapoda is the scientific name for insects.

5. It should be noted that this is my reinterpretation of their work, which was not carried out from a PEA perspective, although inspired by the pragmatist thinking of Charles Sanders Peirce.

6. Purposes are important in helping us to judge what works and does not work, what should be included and not be included. A proximate purpose introduces an activity where students understand "what's going on," and so helps them to make such judgments. Also the game of the adidactic situation is there to help students in this way. Gérard Sensevy expressed it in this way at a meeting in Uppsala, 2011: "A game is something which links intentions and structure. If you understand the game, you understand the intentions of the other players."

7. Not treated extensively in this paper.

\section{REFERENCES}

Brousseau, G. (1997). Theory of Didactical Situations in Mathematics. Dordrecht: Kluwer Academic Publishers.

Caillot, M. (2007). The building of a new academic field: the case of French didactiques. European Educational Research Journal, 6, p. 125-130.

Chevallard, Y. (2007). Readjusting didactics to a changing epistemology. European Educational Research Journal, 6, p. 131-134.

Dewey, J. (1922). Human Nature and Conduct: An Introduction to Social Psychology. New York: Touchstone, Simon and Schuster.

Dewey, J. (1929/1958). Experience and Nature (2e ed.). New York: Dover.

Dewey, J. (1938/1997). Experience and Education. New York: Touchstone, Simon and Schuster.

Dewey, J., \& Bentley, A. F. (1949/1975). Knowing and the known. Westport, Connecticut: Greenwood Press. 
Goffman, E. (1974). Frame Analysis: An Essay on the Organization of Experience. Boston: Northeastern University Press.

Gyllenpalm, J., \& Wickman, P.-O (2011). The Uses of the Term Hypothesis and the Inquiry Emphasis Conflation in Science Teacher Education. International Journal of Science Education, 33, p. 1993-2015.

Hamza, K. M., \& Wickman, P.-O. (2009). Beyond explanations: what else do students need to understand science? Science Education, 93, p. 1026-1049.

Hubber, P., Tytler, R., \& Haslam, F. (2010). Teaching and learning about force with a representational focus: pedagogy and teacher change. Research in Science Education, p. 40, p. 5-28.

Johansson, A.-M. \& Wickman, P.-O. (2011) A pragmatist approach to learning progressions. In Hudson, B. \& Meyer, M. A. (Eds.) Beyond Fragmentation: Didactics, Learning, and Teaching in Europe, p. 47-59. Leverkusen, Germany, Barbara Budrich Publishers.

Lave, J. (1996). The practice of learning. In S. Chaiklin \& J. Lave (Eds.), Understanding practice: perspectives on activity and context (p. 3-32). Cambridge, U.K.: Cambridge University Press.

Ligozat, F., \& Schubauer-Leoni, M.-L. (2009). The joint action theory in didactics: why do we need it in the case of teaching and learning mathematics? In Durand Guerrier, V., Maury, S. \& Arzarello, F. Proceedings of the Sixth Congress of the European Society for Research in Mathematics Education (p. 1615-1624). Lyon: INRP.

Ligozat, F., Wickman, P.-O., Hamza, K. (2011). Using practical epistemology analysis to study the teacher's and students' joint action in the mathematical classroom. In M. Pytlak, T. Rowland, \& E. Swoboda (Eds.) Proceedings of the Seventh Congress of the European Society for Research in Mathematics Education (p. 24722481). University of Rzeszów: Rzeszów, Poland.

Öhman, J., \& Östman, L. (2007). Continuity and change in moral meaning-making: a transactional approach. Journal of Moral Education, 36, p. 151-168.

Östman, L., \& Almqvist, J. (2011). What do values and norms have to do with scientific literacy? In C. Linder, L. Östman, D. A. Roberts, P.-O. Wickman, G. Erickson \& A. MacKinnon (Eds.), Exploring the Landscape of Scientific Literacy (p. 160-175). New York: Routledge.

Roberts, D. A. (1982). Developing the concept of "curriculum emphases" in science education. Science Education, 66, p. 243-260

Rorty, R. (1991). Objectivity, relativism, and truth. Philosophical papers volume I. Cambridge, U.K.: Cambridge University Press.

Sensevy, G. (2009). Outline of a joint action theory in didactics. In Durand Guerrier, V., Maury, S. \& Arzarello, F. Proceedings of the Sixth Congress of the European Society for Research in Mathematics Education (p. 1645-1654). Lyon: INRP.

Sensevy, G. (2011a). Overcoming fragmentation: towards a joint action theory in didactics. In Hudson, B. \& Meyer, M. A. (Eds.) Beyond Fragmentation: Didactics, Learning, and Teaching in Europe (p. 60-76). Leverkusen, Germany: Barbara Budrich Publishers. 
Sensevy, G. (2011b). Patterns of didactic intentions, thought collective and documentation work. In Gueudet, G., Pepin, B., \& Trouche, L. (Eds.) From Text to "Lived" Resources: Mathematics Curriculum Materials and Teacher Development (p. 43-57). New York: Springer.

Sensevy, G., Mercier, A., Schubauer-Leoni, M.-L., Ligozat, F., \& Perrot, G. (2005). An attempt to model the teacher's actions in mathematics. Educational Studies in Mathematics, 59, p. 153-181.

Tiberghien, A. (2007). Legitimacy and references for scientific literacy. In C. Linder, L. Östman \& P.-O. Wickman (Eds.), Promoting Scientific Literacy: Science Education Research in Transaction. Proceedings of the Linnaeus Tercentenary Symposium (p. 130-133). Uppsala: Uppsala University.

Tiberghien, A., Vince, J., \& Gaidioz, P. (2009). Design-based research: case of a teaching sequence on mechanics. International Journal of Science Education, 31, p. 2275-2314.

Wickman, P.-O. (2004). The practical epistemologies of the classroom: a study of laboratory work. Science Education, 88, p. 325-344.

Wickman, P.-O. (2006). Aesthetic Experience in Science Education: Learning and Meaning-Making as Situated Talk and Action. Mahwah, NJ: Lawrence Earlbaum Associates.

Wickman, P.-O, Liberg, C. \& Östman, L. (in press) Transcending science: scientific literacy and bildung for the 21 st century. Jorde, D. \& Dillon, J. (Eds.) Science Education Research in Europe. Volume IV of The World of Science Education (Series Eds. Tobin, K. \& Roth, W.-M..) Rotterdam, Sense Publishers.

Wickman, P.-O., \& Ligozat, F. (2011). Scientific literacy as action: consequences for content progression. In C. Linder, L. Östman, P.-O. Wickman, D. A. Roberts, G. Erickson \& A. MacKinnon (Eds.), Exploring the Landscapes of Scientific Literacy (p. 145-159). New York: Routledge.

Wickman, P.-O., \& Östman, L. (2002a). Learning as discourse change: a sociocultural mechanism. Science Education, 86, p. 601-623.

Wickman, P.-O., \& Östman, L. (2002b). Induction as an empirical problem: how students generalize during practical work. International Journal of Science Education, 24, p. 465-486.

Wittgenstein, L. (1967). Philosophical investigations (3e ed.). Oxford, U.K.: Blackwell.

Wittgenstein, L. (1969). On certainty. Oxford, U.K.: Blackwell. 